\title{
Gastric volvulus as a deadly cause of acute abdominal pain: Presentation of three cases
}

\author{
Ahmet Türkan'(D), Metin Yalaza² (D), Gökhan Akkurt³ (D), Mehmet Tolga Kafadar ${ }^{4}$ (D) \\ ${ }^{1}$ Clinic of General Surgery, Elbistan State Hospital, Kahramanmaraş, Turkey \\ ${ }^{2}$ Clinic of General Surgery, Health Sciences University Numune Training and Research Hospital, Ankara, Turkey \\ ${ }^{3}$ Clinic of General Surgery, Health Sciences University Keçiören Training and Research Hospital, Ankara, Turkey \\ ${ }^{4}$ Clinic of General Surgery, Health Sciences University Mehmet Akif Inan Training and Research Hospital, Şanlıurfa, Turkey
}

\begin{abstract}
Gastric volvulus is usually associated with non-specific abdominal pain and is a very rare condition. Diagnosis of gastric volvulus is difficult because of the lack of specific findings. Its acute form usually requires urgent surgical treatment and is associated with high mortality. In this study, gastric volvulus was diagnosed in three patients who presented with abdominal pain in the emergency department and had non-specific abdominal findings on physical examination. We evaluated this situation, which is rarely seen, on different patients.
\end{abstract}

Keywords: Gastric volvulus, acute, abdomen

Cite this article as: Türkan A, Yalaza M, Akkurt G, Kafadar MT. Gastric volvulus as a deadly cause of acute abdominal pain: Presentation of three cases. Turk J Surg 2021; 37 (2): 183-187.

\section{Corresponding Author}

Mehmet Tolga Kafadar

E-mail: drtolgakafadar@hotmail.com

Received: 01.06 .2018

Accepted: 20.06 .2018

Available Online Date: 30.06.2021

O Copyright 2021 by Turkish Surgical Society Available online at www.turkjsurg.com

DOI: $10.47717 /$ turkjsurg.2021.4232

\section{INTRODUCTION}

Gastric volvulus is a rare condition that can occur at different degrees of rotation of the stomach along the long axis (organo-axial) on transverse plain (mesentero-axial) as combined or unclassified form, and can cause different clinical conditions. The stomach usually causes organo-axial rotation as a result of herniation of the defect of the diaphragm (1). Primary gastric volvulus is often blamed for laxity of the gastric ligaments. The Borchardt triad, which is clinically characterized by severe epigastric pain accompanied by abdominal distension, inability of vomiting despite gag reflex, and failure to insert a nasogastric tube can be seen in many patients with gastric volvulus (2). This study aimed to present three cases diagnosed with acute gastric volvulus.

\section{CASE 1}

A 65-year-old female patient was admitted in the emergency department with complaints of sudden onset abdominal pain and distention. On physical examination, there were significant abdominal distention prominently in the epigastric region and diffuse abdominal tenderness. Patient anamnesis revealed that the patient had been suffering of dyspeptic complaints for a long time. An urgent laparotomy was performed for the lethargic patient with arterial blood pressure of $60 / 30 \mathrm{mmHg}$. During exploration, it was found that the stomach was expanded excessively, associated with rotation in the pylorocardic axis (organo-axial volvulus), and a necrosis has developed in an area with dimensions of $4 \times 2 \mathrm{~cm}$ in the lesser curvature. In addition, the splenic capsule was observed with active hemorrhage due to laceration. No macroscopic pathology which could explain the volvulus was detected except gastrocolic and hepatogastric ligament agenesis and stenosis, which may be consistent with the fibrotic band of the pylori (Figure 1). Distal subtotal gastrectomy, Roux $\mathrm{N}-\mathrm{Y}$ gastrojejunostomy and splenectomy were performed. Gastrojejunal fistula and further gastric atonia emerged in post-operative period and the patient who treated without operation was discharged on day 34 without any complaint. Pathological study was reported as 'pyloric stenosis and chronic inflammation. Informed consent was obtained from the son of the patient. 


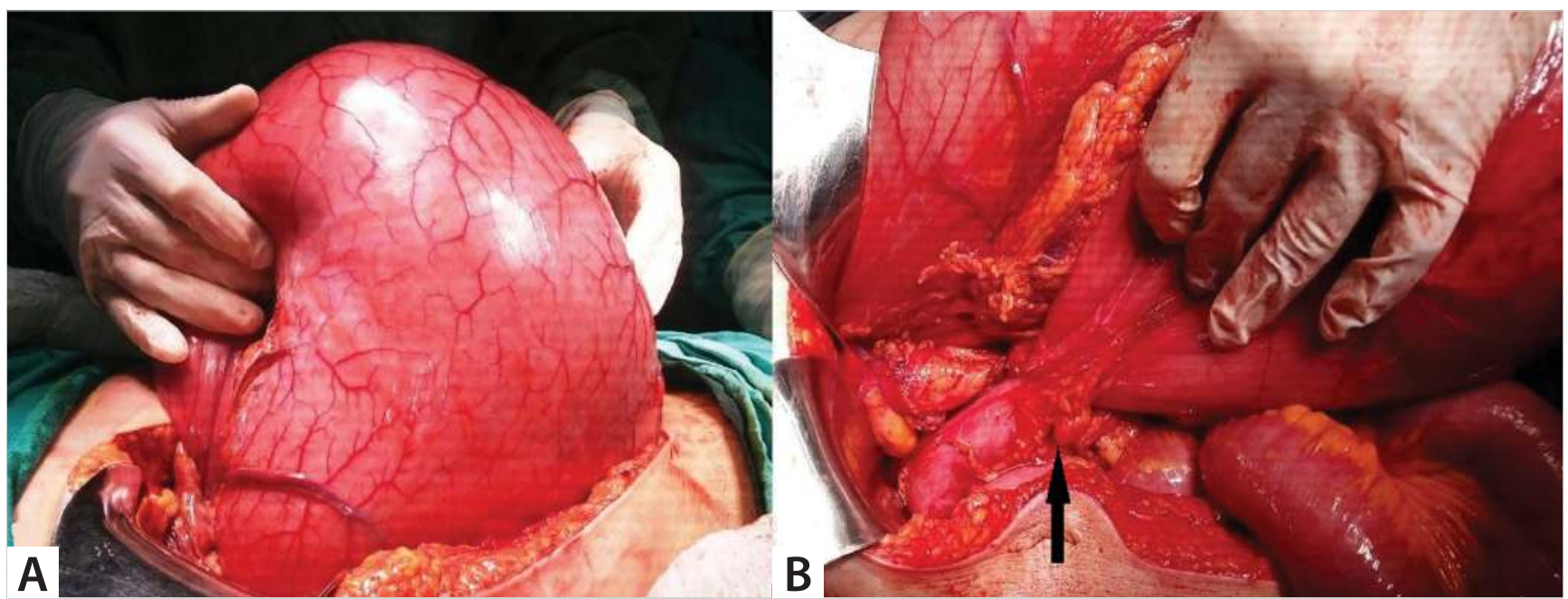

Figure 1. A. Gastricorgano-axial volvulus. B. Pylor (black arrow). The stomach is seen dilated due to pyloric stenosis but the duodenum is collapsed.

\section{CASE 2}

A 78-year-old female patient was admitted in the emergency department with complaints of sudden onset abdominal pain and distention. According to anamnesis taken during the application, it was found out that she had chronic obstructive pulmonary disease (COPD) and history of gastric hemorrhage that occurred a year ago. On physical examination, there were abdominal distention, diffuse tenderness and defense. Tests resulted with white blood cell (WBC): $7.4 \mathrm{~K} / \mathrm{ul}$, hemoglobin (Hb): 11.5 g/dl, Creatinine: $1.87 \mathrm{mg} / \mathrm{dl}$, C-reactive protein (CRP): $40 \mathrm{mg} / \mathrm{L}$, Glucose: 130 mg/dl. Paraesophageal hernia, intraabdominal free air and fluid were detected on the abdominal computed tomography (CT) (Figure 2). Patient was preliminarily diagnosed with gastric perforation and emergency surgery was performed.
During exploration, it was found that the stomach was localized mostly in the thoracic cavity, organo-axial gastric volvulus has developed, the omentum and the transverse colon had elevated up to the diaphragm, and splenic hemorrhage had occurred due to diaphragmatic hernia. In addition, there was a post-pyloric perforation approximately $0.5 \mathrm{~cm}$ in diameter. Splenectomy was performed because hemorrhage could not be controlled. The stomach was taken into the abdomen and detorsed. No gastric ischemia was identified. The focus perforation of the post-pyloric region was primarily repaired by suturing and an omentopexy was performed. The diaphragmatic defect was repaired by suturing one-by-one using silk suture No. 1 after providing sufficient space in peripheral of the esophagus. The gastric corpus-anterior surface was sutured on the abdominal anterior wall

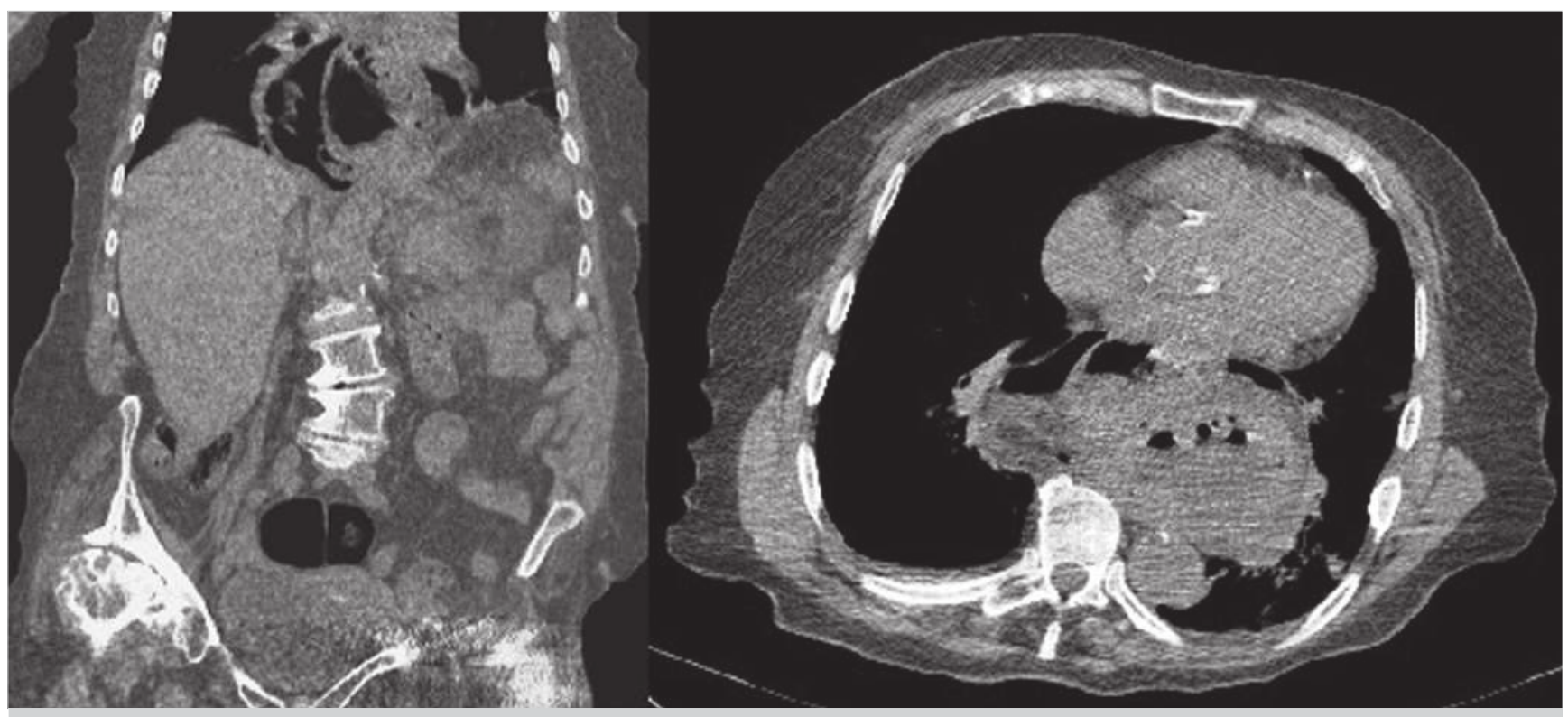

Figure 2. Tomographic image of the para-esophageal hernia. 
using 3.0-Prolene sutures one-by-one and a gastropexy was performed. The patient had no drainage through catheters, her vital signs were stable, and she started on oral feeding on post-operative day seven and tolerated it. The patient who was known to have COPD previously was followed up by the Department of Chest Diseases with the diagnosis of post-operative pneumonia. The patient was transferred to intensive care unit and intubated on post-operative day 21 due to respiration arrest and started on mechanical ventilation support. The patient's enteral nutrition was maintained, spontaneous stool defecation occurred, and the patient died on post-operative day 51 due to respiratory problems. Informed consent was obtained from the son of the patient.

\section{CASE 3}

A 75-year-old male patient was admitted in the emergency department with complaints of sudden onset abdominal pain and distention. It was found out that the patient was followed up for Chronic Lymphocytic Leukemia, stricture of the pylori detected during gastroscopy conducted for dyspepsia and patient had been suffering from dyspeptic complaints since then. It was further found out that the patient had relaxed spontaneously when transferring to a medical center due to the diagnosis of acute gastric volvulus six months ago. Physical examination showed abdominal distention and diffuse tenderness. Tests resulted with WBC: $11.69 \mathrm{~K} / \mathrm{ul}, \mathrm{Hb}: 10.1 \mathrm{~g} / \mathrm{dl}$, Creatinine: $1.69 \mathrm{mg} / \mathrm{dl}$, CRP: 49.6 mg/L, Glucose: 190 mg/dl. Abdominal CT scan was found consistent with acute gastric volvulus (Figure 3). The patient, for whom emergency surgical treatment was planned, left the hospital voluntarily, not accepting the treatment, even though he was informed that he had a life-threatening risk. The patient was brought to the emergency department about 24 hours later in arrest condition. The patient without response to cardiac resuscitation died. Informed consent was obtained from the son of the patient.

\section{DISCUSSION}

Gastric volvulus can occur due to the secondary causes such as diaphragmatic hernia of the stomach, pyloric stenosis, intra-abdominal adhesions, and peptic ulcers and/or tumors that cause the stomach torsion causing retraction of the minor curvature. Primary gastric volvuli are often blamed for laxity of the gastric ligaments (2,3). The first patient had collapse of the duodenum and severe gastric dilation secondary to pyloric stenosis. That patient also had gastrocolic and hepatogastric ligament agenesis. The second patient had diaphragmatic hernia, and the third patient had known pyloric stenosis.

Gastric volvulus usually has a chronic and asymptomatic course. Symptomatic ones are associated with nonspecific dyspeptic complaints such as epigastric pain and feeling of abdominal distention. In some cases, respiratory problems due to diaphragmatic hernia can also be seen. In acute gastric volvulus, clinical picture is more complex and patients usually admit due to acute abdominal findings. Although the presence of the Borchardt triad is suggestive of gastric volvulus, its absence does not exclude the diagnosis (4). All of the patients had complaints of sudden onset severe abdominal pain and severe abdominal distention. It was found out that the first patient had been suffering from dyspeptic complaints for a long time.

Barium passage graphy and CT help the diagnosis of gastric volvulus (5). In addition, esophagogastroduodenoscopy, which can

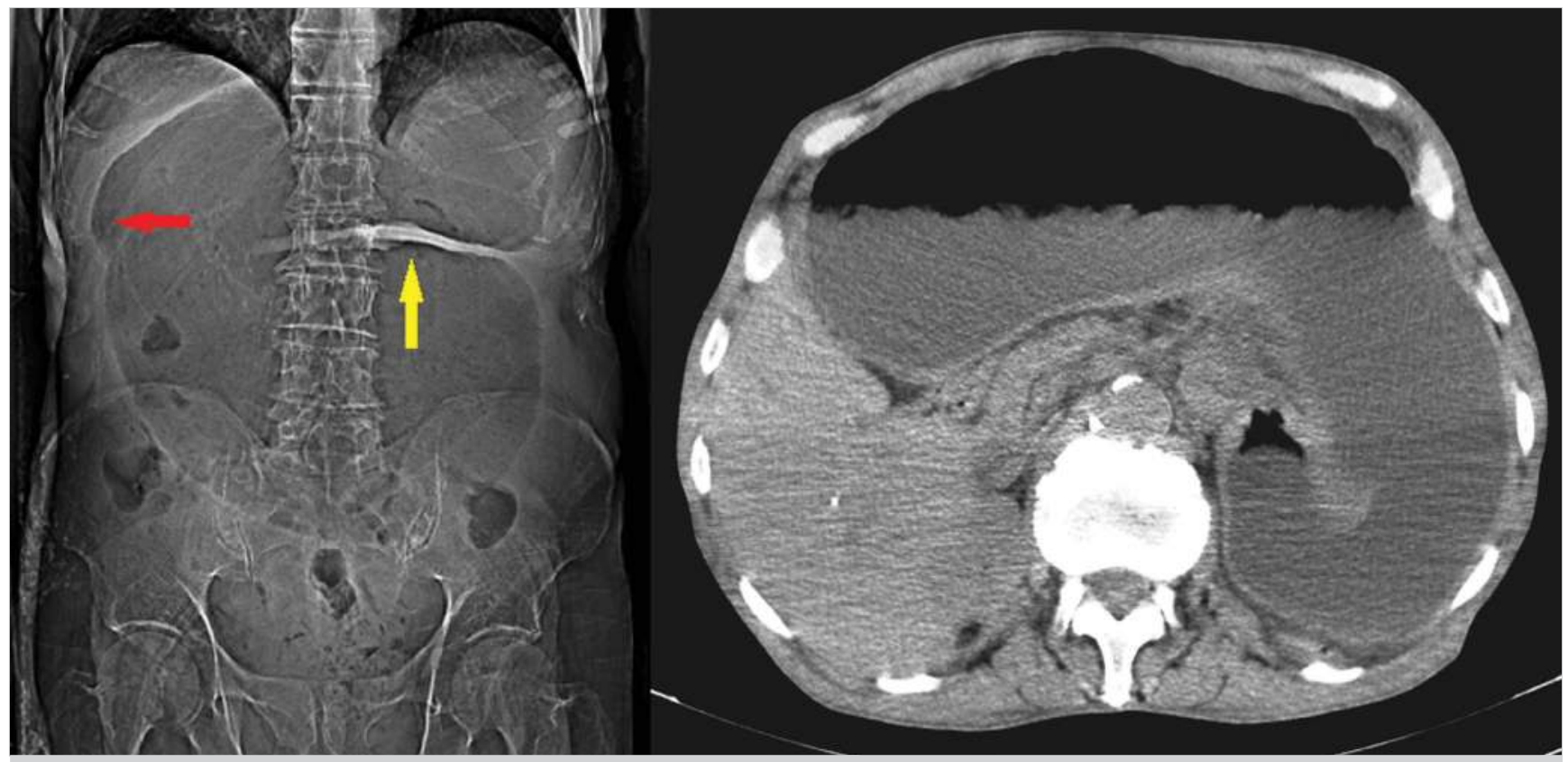

Figure 3. Gastric organo-axial volvulus tomography image. Lesser curvature (yellow arrow), greater curvature (red arrow). 
be used in patients with stable disease, can be used in both diagnosis and treatment to provide detorsion. CT continues to be a key diagnostic imaging for gastric volvulus because of its success in diagnosis, its rapidity, its 24-hour accessibility, its ability to assess the presence of necrosis or perforation of the gastric wall, and the possibility of planning treatment (6). The first patient, who was lethargic and hemodynamically unstable, underwent an emergency laparotomy without further tests and evaluations. $\mathrm{CT}$ of the second patient was consistent with para-esophageal hernia and gastrointestinal perforation, whereas CT of the third patient was consistent with acute gastric volvulus.

Although a conservative approach may be considered in selected cases, the treatment of gastric volvulus is surgery. Conservative treatment can only be considered for hemodynamically stable patients. Zuiki et al. have successfully treated a patient diagnosed with acute mesentero-axial gastric volvulus by endoscopic detorsion and gastropexy (6). Surgical treatment can be done by open or laparoscopic method. It usually includes procedures for the secondary cause leading to gastric volvulus and gastric fixation. Anterior gastroparesis or fundoplication may be preferred in gastric fixation. The results of both techniques are successful, and the technique to be applied depends on the condition of the patient $(7,8)$. If there is gastric perforation or necrosis, resection must be performed (9). The Billroth two operation was performed for the necrosis of the gastric lesser curvature of the first patient. The second patient had no any ischemic focus. After post-pyloric perforation focus and diaphragmatic defect were repaired, anterior gastroparesis was performed.

Acute gastric volvulus should be treated without delay due to high mortality risk. Mortality level has been reported 30\% in the case of presence of necrosis and perforation. The most common post-operative complication is pneumonia and long-term stay in intensive care. This is considered to be associated with the fact that patients are generally older and comorbid (8). The fistula of the patient with gastrojejunal anastomosis leakage was closed by treatment without operation. However, patient's length of stay was extended due to gastric atonia emerged accordingly. The second patient with known COPD died because of respiratory failure secondary to pneumonia that emerged within the post-operative period. The third patient, who refused the treatment and died in a short time of 24 hours, is considered a good example demonstrating the importance of quick treatment.

\section{CONCLUSION}

While the chronic form often has an asymptomatic course, acute gastric volvulus is potentially life threatening and may be associated with high mortality rates. Early diagnosis and early surgical intervention can be life-saving for gastric volvuli.

Ethics Committee Approval: Retrospective case study.

Informed Consent: Informed consent was obtained from the son of the patients.

Peer-review: Externally peer-reviewed.

Author Contributions: Concept - A.T., M.T.K.; Design - M.Y., G.A.; Supervision - M.Y., M.T.K.; Materials - A.T., G.A.; Data Collection and/or Processing - A.T., M.Y., G.A.; Analysis and/or Interpretation - A.T., M.Y., G.A., M.T.K.; Literature Search A.T., M.T.K.; Writing Manuscript - A.T., M.T.K.; Critical Reviews - M.T.K.

Conflict of Interest: No conflict of interest was declared by the authors.

Financial Disclosure: The authors declared that this study has received no financial support.

\section{REFERENCES}

1. Rashid F, Thangarajah T, Mulvey D, Larvin M, Iftikhar SY. A review article on gastric volvulus: a challenge to diagnosis and management. Int J Surg 2010; 8(1): 18-24. [CrossRef]

2. Germanos S, Gourgiotis S, Saedon M, Lapatsanis D, Salemis NS. Severe abdominal pain as a result of acute gastric volvulus. Int J Emerg Med 2010; 3(1):61-2. [CrossRef]

3. Jacob CE, Lopasso FP, Zilberstein B, Bresciani CJC, Kuga R, Cecconello 1, et al. Gastric volvulus - a review of 38 cases. ABCD Arq Bras Cir Dig 2009; 22(2): 96-100. [CrossRef]

4. Senior A, Hari C. A rare case of acute on chronic gastric volvulus with Borchardt's triad. J Surg Case Rep 2014; 2014(11): rju114. [CrossRef]

5. Chau B, Dufel S. Gastric volvulus. Emerg Med J 2007; 24(6): 446-7. [CrossRef]

6. Zuiki T, Hosoya Y, Lefor AK, Tanaka H, Komatsubara T, Miyahara Y, et al. The management of gastric volvulus in elderly patients. Int J Surg Case Rep 2016; 29: 88-93. [CrossRef]

7. Lee HY, Park JH, Kim SG. Chronic gastricvolvulus with laparoscopic gastropexy after endoscopic reduction: a case report. J Gastric Cancer 2015; 15(2): 147-50. [CrossRef]

8. Light D, Links D, Griffin M. The threatened stomach: management of the acute gastric volvulus. Surg Endosc 2016; 30(5): 1847-52. [CrossRef]

9. Schianodi VM, Barbaresco S, Burelli P, Da Ros D, Di Bella R, Lombardo C, et al. Acute abdomen due to a strangulated and perforated para-esophageal hernia. A case report. Chir Ital 2002; 54(4): 563-7. [CrossRef] 


\section{OLGU SERISI-ÖZET}

Turk J Surg 2021; 37 (2): 183-187

\section{Akut abdominal ağrının ölümcül bir nedeni olarak gastrik volvulus: Üç olgunun sunumu}

Ahmet Türkan ${ }^{1}$, Metin Yalaza ${ }^{2}$, Gökhan Akkurt ${ }^{3}$, Mehmet Tolga Kafadar ${ }^{4}$

${ }^{1}$ Elbistan Devlet Hastanesi, Genel Cerrahi Kliniği, Kahramanmaraş, Türkiye

${ }^{2}$ SBÜ Numune Eğitim ve Araştırma Hastanesi, Genel Cerrahi Kliniği, Ankara, Türkiye

${ }^{3}$ SBÜ Keçiören Eğitim ve Araştırma Hastanesi, Genel Cerrahi Kliniği, Ankara, Türkiye

${ }^{4}$ SBÜ Mehmet Akif İnan Eğitim ve Araştırma Hastanesi, Genel Cerrahi Kliniği, Şanlıurfa, Türkiye

\section{ÖZET}

Gastrik volvulus genellikle non-spesifik karın ağıısı ile ilişkilidir ve çok nadir bir durumdur. Gastrik volvulus tanısı, spesifik bulguların eksikliği nedeniyle zordur. Akut formu genellikle acil cerrahi tedavi gerektirir ve yüksek mortalite ile ilişkilidir. Acil serviste abdominal ağrı ile başvuran ve fizik muayenede non-spesifik abdominal bulguları olan üç hastada gastrik volvulus tanısı kondu. Bu sunumda, nadir görülen bu klinik durumu farklı hastalarda değerlendirdik.

Anahtar Kelimeler: Gastrik volvulus, akut, karın

Doi: 10.47717/turkjsurg.2021.4232 